\title{
Penerapan Pendekatan Kontekstual dengan Memanfaatkan Internet Sebagai Sumber Belajar untuk Meningkatkan Hasil Belajar Siswa pada Mata Pelajaran Mulok Materi Ragam Patu Mbojo di SMAN 4 Kota Bima Kelas X MIPA-2 Semester Ganjil Tahun Pelajaran 2020/2021
}

\author{
Afdhalina \\ SMA Negeri 4 Kota Bima, Kota Bima, Indonesia \\ *Coresponding Author: afdhalinailyas@gmail.com \\ Dikirim: 19-08-2021; Direvisi: 24-10-2021; Diterima: 25-10-2021
}

\begin{abstract}
Abstrak: Hasil pembelajaran pra-siklus yang telah dilakukan peneliti, menunjukkan hasil belajar siswa rendah, rata-rata nilai formatif tes siswa yakni rata-rata 65.00 dengan porsentase ketuntasan 68.00, nilai ini masih dibawah indikator yang ditetapkan 75.00 ketuntasan klasikal 85.00. Berdasarkan latar belakang masalah, identifikasi masalah, maka peneltan perbaikan pembeljaran ini dapat dirumuskan sebagai berikut: Bagaimana penerapan pendekatan kontekstual dengan memanfaatkan internet sebagai sumber belajar untuk meningkatkan hasil belajar siswa pada mata pelajaran Mulok materi ragam patu mbojo di SMAN 4 Kota Bima kelas X MIPA-2 semester ganjil tahun pelajaran 2020/2021?. Tujuan Penelitian: 1. Mendeskripsikan proses penerapan pendekatan kontekstual dengan memanfaatkan internet sebagai sumber belajar untuk meningkatkan hasil belajar siswa pada mata pelajaran Mulok materi ragam patu mbojo di SMAN 4 Kota Bima kelas X MIPA-2 semester ganjil tahun pelajaran 2020/2021. 2. Mendeskripsikan dan menganalisis dampak penerapan pendekatan kontekstual dengan memanfaatkan internet sebagai sumber belajar untuk meningkatkan hasil belajar siswa pada mata pelajaran Mulok materi ragam patu mbojo di SMAN 4 Kota Bima kelas X MIPA-2 semester ganjil tahun pelajaran 2020/2021. Teknik pengumpulan data meliputi pengamatan, dokumen dan tes. Peningkatan hasil belajar siswa ini dapat dibandingkan dari hasil tes pra-perbaikan. Perbaikan dilaksanakan dalam 2 (dua) siklus. Siklus I dari tanggal 13 Juli 2020 sampai dengan 24 Juli 2020 dan siklus II dilaksanakan tanggal 16 Agustus 2020 sampai dengan 27 Agustus 2020. Subyek perbaikan adalah siswa kelas X MIPA-2 SMAN 4 Kota Bima dengan jumlah siswa 31, terdiri dari 13 orang laki-laki dan 18 orang perempuan. Terjadi peningkatan hasil belajar siswa ini dapat dibandingkan dari hasil tes pra-perbaikan. Hasil pos tes siklus I diatas menunjukkan bahwa prestasi belajar siswa rata-rata $68.44(+3.44)$, Persentase ketuntasan $71.00 \%(+3.00)$, Persentase ini masih dibawah indikator kinerja yakni $\geq 85.00 \%$. Dari sisi prestasi belajar siklus I (pertama) belum berhasil. APKG I, untuk perencanaan pembelajaran yang mendidik $\geq 90.50(+2.00)$ APKG II, untuk pelaksanaan pembelajaran yang mendidik $\geq 89.00(+4.00)$. Dengan demikian dari sisi kinerja guru siklus I belum mencapai indikator kinerja yang ditetapkan yakni APKG I dan APKG II $\geq 92.00$. Hasil pos tes siklus II menunjukkan bahwa prestasi belajar siswa rata-rata $80.00(+11.56)$. Persentase ketuntasan $85.00 \%(+14.00)$. Persentase ini telah memenuhi indikator kinerja yakni $\geq 85.00 \%$. Dengan demikian pada siklus II ini telah berhasil mencapai indikator yang ditetapkan yakni rata-rata $\geq 75.00$ dan persentase ketuntasan $\geq 85.00 \%$. Dari sisi prestasi belajar siklus II (kedua) telah berhasil. APKG I, untuk perencanaan pembelajaran yang mendidik $\geq 92.20(+1.70)$ APKG, II untuk pelaksanaan pembelajaran yang mendidik $\geq 92.30(+3.30)$. Dengan perbaikan proses pembelajaran berhasil memenuhi indikator kinerja yang ditetapkan yakni APKG I, untuk perencanaan $\geq 92.00$ APKG II, untuk pelaksanaan $\geq 92.00$. Peningkatkan Prestasi belajar siswa, disebabkan efektivitas penerapan pendekatan kontekstual dengan memanfaatkan
\end{abstract}


media internet sebagai sumber belajar dengan pemanfaatan internet sebagai sumber belajar yang dilaksanakan guru. Dengan demikian setelah pelaksanaan perbaikan pembelajaran sampai siklus II, telah mencapai indikator kinerja yang ditetapkan, dan penelitian dianggap telah berhasil.

Kata Kunci: Penerapan pendekatan kontekstual; internet sebagai sumber belajar

Abstract: The results of pre-cycle learning that have been carried out by researchers, show low student learning outcomes, the average formative test scores of students are an average of 65.00 with a completeness percentage of 68.00 , this value is still below the indicator set at 75.00 classical completeness of 85.00. Based on the background of the problem, problem identification, then this learning improvement research can be formulated as follows: How to apply a contextual approach by utilizing the internet as a learning resource to improve student learning outcomes in the Mulok subject matter of patu mbojo variety at SMAN 4 Kota Bima class X MIPA- 2 odd semesters for the 2020/2021 school year? Research Objectives: 1. Describe the process of applying a contextual approach by utilizing the internet as a learning resource to improve student learning outcomes in the Mulok subject matter of the variety of patu mbojo at SMAN 4 Kota Bima class X MIPA-2 in the odd semester of the 2020/2021 school year. 2. Describe and analyze the impact of applying a contextual approach by utilizing the internet as a learning resource to improve student learning outcomes in the Mulok subject matter of mbojo patu variety at SMAN 4 Kota Bima class X MIPA-2 in the odd semester of the 2020/2021 school year. Data collection techniques include observations, documents and tests. This improvement in student learning outcomes can be compared from the results of the pre-improvement test. Repairs are carried out in 2 (two) cycles. Cycle I was from July 13, 2019 to July 24, 2019 and cycle II was held from August 16, 2019 to August 27, 2019. The subjects of the improvement were students of class X MIPA-2 SMAN 4 Kota Bima with a total of 31 students, consisting of 13 boys. male and 18 female. An increase in student learning outcomes can be compared from the results of the pre-remedial test. The results of the post-test cycle I above show that the average student achievement is $68.44(+3.44)$, the percentage of completeness is $71.00 \%(+3.00)$, this percentage is still below the performance indicator, namely $85.00 \%$. In terms of learning achievement, the first (first) cycle has not been successful. APKG I, for educational lesson planning $90.50(+2.00)$ APKG II, for educational learning implementation $89.00(+4.00)$. Thus, in terms of teacher performance in cycle I, the performance indicators have not yet reached the set performance indicators, namely APKG I and APKG II 92.00. The results of the post-test cycle II showed that the average student achievement was $80.00(+11.56)$. The percentage of completeness is $85.00 \%(+14.00)$. This percentage has met the performance indicator, namely $85.00 \%$. Thus, in the second cycle, it has succeeded in achieving the specified indicators, namely an average of 75.00 and a percentage of completeness $85.00 \%$. In terms of learning achievement, cycle II (second) has been successful. APKG I, for educational lesson planning $92.20(+1.70)$ APKG, II for educational learning implementation 92.30 (+3.30). By improving the learning process, the performance indicators have been met, namely APKG I, for planning 92.00 APKG II, for implementation 92.00. The increase in student achievement is due to the effectiveness of the application of a contextual approach by utilizing the internet as a learning resource with the use of the internet as a learning resource carried out by the teacher. Thus, after the implementation of learning improvements up to cycle II, the performance indicators have been achieved, and the research is considered successful.

Keywords: Application of contextual approach; internet as a learning resource

\section{PENDAHULUAN}


Dalam lampiran Permendikbud Nomor 22 Tahun 2016 Tentang Standar Proses disebutkan bahwa proses pembelajaran pada satuan pendidikan diselenggarakan secara interaktif, inspiratif, menyenangkan, menantang, memotivasi pesertadidik untuk berpartisipasi aktif, serta memberikan ruang yang cukup bagi prakarsa, kreativitas, dan kemandirian sesuai dengan bakat, minat, dan perkembangan fisik serta psikologis peserta didik. Untuk itu setiap satuan pendidikan melakukan perencanaan pembelajaran, pelaksanaan proses pembelajaran serta penilaian proses pembelajaran untuk meningkatkan efisiensi dan efektivitas ketercapaian kompetensi lulusan.

Dalam UU Sikdiknas No. 20 tahun 2003, temyata telah disadari penerimaan pengakuan bahwa sudah bukan masanya mengandalkan pendekatan konvensional saja dalam menyelenggarakan sistem pendidikan nasional. Bukan hanya di ruang tertutup dengan buku dan pendidik yang setiap saat ditemui, diminta tolong menunjukan sumber informasi peserta didik dapat memenuhi hasratnya lebih pintar, lebih cerdas, lebih baik, dan lebih sejahtera dalam hidupnya. Bagaimanapun juga transformasi pesan pembelajaran dengan mendayagunakan kemajuan teknologi pendidikan kiranya akan lebih memotivasi peserta didik.

Pendidikan merupakan proses belajar dalam membentuk cara berpikir baik buruk seseorang maupun pola perilakunya. Proses pendidikan tidak hanya berlangsung di lingkungan sekolah saja, tetapi juga di lingkungan luar sekolah, seperti lingkungan bermain, lingkungan masyarakat ataupun lingkungan keluarga. Pendidikan mempunyai peranan penting dalam menciptakan dan mengembangkan sumber daya manusia yang berkualitas baik serta berguna bagi dirinya sendiri, masyarakat sekitar serta bangsanya. Pendidikan adalah usaha sadar dan terencana untuk mewujudkan suasana belajar dan proses pembelajaran agar peserta didik secara aktif mengembangkan potensi dirinya untuk memiliki kekuatan spiritual keagamaan, pengendalian diri, kepribadian, kecerdasan, akhlak mulia, serta keterampilan yang diperlukan dirinya, masyarakat, bangsa dan negara.

Pada pelaksanaan pembelajaraan pra-siklus, meskipun telah mengggunakan Kurikulum 2013 dengan Standar Prosesnya yang telah disebutkan sebelumnya, akan tetapi penliti tidak memperhatikan perbedaan karakteristik peserta didik. Dengan lain perkataan peneliti tidak mempertimbangkan perbedaan karakteristik untuk merancang model pembelajaran, motode pembelajaran yang sesuai. Metode yang peneliti gunakan adalah ceramah dan tanya jawab lisan.

Dalam proses pembelajaran sumber informasi tidaklah didapatkan melalui guru maupun buku saja, melainkan sumber informasi bagi peserta didik dapat dikembangkan dengan memanfaatkan kemajuan teknologi seperti melalui internet yang dapat mengembangkan motivasi serta kreatifitas peserta didik. Dengan mengakses informasi dari berbagai media yang ada khususnya internet sehingga memunginkan peserta didik lebih dahulu mengetahui dibanding gurunya, tentu saja kondisi ini merupakan gejala yang positif sekaligus tantangan bagi para guru untuk memperbaiki proses pembelajarannya. Dalam proses penyusunan perencanaan program pembelajaran guru perlu menetapkan metode yang relefan serta sumber apa yang dapat digunakan oleh siswa agar mereka dapat mencapai tujuan yang telah ditentukan. Dalam pengajara tradisional, seringkali guru menggunakan buku sebagai satuu-satunya sumber belajar. Itupun biasanya hanya menggunakan satu buku paket. 
Proses pembelajaran pada dasarnya juga merupakan proses komunikasi, sehingga media yang digunakan dalam pembelajaran disebut media pembelajaran. Menurut Gagne "media sebagai komponen dalam lingkungan siswa yang dapat merangsang mereka untuk belajar", senada dengan pendapat Briggs "meedia sebagai alat untuk memberikan perangsang bagi siswa agar terjadi proses belajar. Sumber belajar memiliki cakupan yang lebih luas dari pada media belajar, sumber belajar bisa berupa pesan, orang, baahan, alat, teknik, dan latar/lingkungan.

Pada observasi awal yang dilakukan peneliti di SMAN 4 Kota Bima, peneliti mengikuti proses pembelajaran didalam kelas ketika guru memanfaatkan internet dan buku sebagai sumber belajar untuk mengerjakan tugas pada mata pelajaran Mulok, sangat terlihat bahwa siswa lebih sering mengakses internet dari pada membaca buku paket dan LKS mata pelajaran Mulok. Untuk mencari informasi yang diinginkan tetapi penggunaan internet belum maksimal dikarenakan siswa hanya sekadar mencari materi yang sesuai dengan tugas yang diberikan saja tanpa membaca dengan memahami isi materi yang didapatkan, rendahnya minat membaca buku pada siswa membuat siswa sulit memahami materi pelajaran sehingga informasi dan pengetahuan yang didapat oleh siswa belum maksimal. Hal ini ditunjukkan dengan kondisi proses pembelajaran yang tidak interaktif, siswa cenderung pasif dan rendahnya prakarsa dan hasil belajar siswa, serta tingginya dominasi guru dalam proses pembelajaran.

Dampaknya dari metode yang tidak tepat dan dari proses pembelajaran prasikluspun rendah. Sebanyak $20 \%$ siswa yang tidak mengerjakan tugas dengan baik, bahkan 30\% siswa tidak mengerjakan tugas sama sekali. Dengan kondisi ini prestasi belajar siswa rendah. Rata Demikian pula kinerja guru yang diukur dengan APKG 1 dan APKG 2 rendah. Nilai APKG 1, untuk perencanaan pembelajaran 83.00 dan APKG 2, pelaksanaan pembelajaran 82.00. Nilai ini dibawah indikator knerja guru yang ditetapkan yakni APKG 1, untuk perencanaan pembelajaran 92.00 dan APKG 2, pelaksanaan pembelajaran 92.00. rata-rata 65.00 dengan porsentase ketuntasan 68.00, nilai ini masih dibawah indikator yang ditetapkan 75.00 ketuntasan klasikal 85.00. Untuk memperbaiki proses dan meningatkan hasil belajar peneliti menerapkan pendekatan kontekstual dengan memanfaatkan internet sebagai sumber belajar pada mata pelajaran Mulok materi ragam patu mbojo di SMAN 4 Kota Bima kelas X MIPA-2 semester ganjil Tahun Pelajaran 2020/2021.

\section{KAJIAN TEORI}

\section{Pemanfaatan Internet sebagai Sumber Belajar}

\section{Internet sebagai Sumber Belajar}

Menggunakan internet dengan segala fasilitasnya akan memberikan kemudahan untuk mengakses berbagai informasi untuk pendidikan yang secara langsung dapat meningkatkan pengetahuan siswa bagi keberhasilannya dalam belajar. Internet merupakan sumber informasi utama dan pengetahuan, melalui teknologi ini kita dapat melakukan beberapa hal, diantaranya untuk: penelusuran dan pencarian bahan pustaka, membangun program artficial intelligence (kecerdasan buatan) untuk memodelkan sebuah rencana pembelajaran, memberi kemudahan untuk mengakses apa yang disebut dengan virtual classroom ataupun virtual university, pemasaran dana promosi hasil karya penelitian. 
Sumber belajar merupakan komponen sistem instruksional yang meliputi pesan, bahan, alat, teknik dan lingkungan yang mana dapat berpengaruh hasil belajar siswa. Pemanfaatan internet sebagai sumber pembelajaran, dapat diimplementasikan melalui cara Browsing (menjelajahi dunia rnaya), Searching (pencarian surnber bahan belajar), Resourcing (internet untuk sumber bahan belajar), Consulting and Communicating (Konsultasi dan komunikasi)

Sumber Belajar adalah segala tempat atau lingkungan sekitar, benda, dan orang yang mengandung informasi dapat digunakan sebagai wahana bagi peserta didik untuk melakukan proses perubahan tingkah laku. Sumber belajar dapat dikategorikan sebagai berikut:

\section{Cara Memanfaatkan Teknologi Informasi atau Internet untuk Pembelajaran}

Menurut Sadiman menyatakan bahwa perubahan dan perkembangan yang berlaku dengan cepat, memerlukan penyediaan sumber belajar yang aktual, kaya informasi dan mudah terjangkau. Internet adalah teknologi yang telah memberikan landasan kuat bagi terciptanya lingkungan belajar yang kaya dan luwes, serta mampu memenuhi pendidikan dan latihan. Internet adalah jaringan dari jaringan, sebagaimana jaringan telepon yang mengkomunikasikan suara, internet mengkomunikasikan data.

Menurut Bambang Warsita secara umum, ada tiga cara memanfaatkan ternologi informasi untuk kegiatan pembelajaran, yaitu Web Course, Web Centric Course, dan Web Enhanced Course

\section{Sumber Belajar}

Sumber belajar adalah "segala daya yang dapat dimanfaatkan guna memberikan kemudahan kepada seseorang dalam belajarnya. Sesungguhnya sumber belajar itu banyak jenisnya. Adapun sumber belajar itu meliputi pesan (message), orang (People), bahan (materials), alat (device), teknik (tehnique), lingkungan (setting), dan lainnya yang bisa digunakan untuk memberikan kemudahan bagi siswa dalam belajar dan menambah pengetahuannya. Dengan sumber belajar tersebut maka siswa mendapatkan fasilitas yang dapat memungkinkannya untuk belajar dengan baik.

Implementasi pemanfaatan sumber belajar di dalam proses pembelajaran tercantum dalam kurikulum saat ini bahwa dalam proses pembelajaran yang menggunakan berbagai ragam sumber belajar. AECT (Association for Education Communication and technology) membedakan enam jenis sumber belajar yang dapat digunakan dalam proses belajar, yaitu pesan (Message), orang (People), bahan (Matterials), alat (Divice), teknik (Technique), dan latar (Setting).

\section{Pembelajaran Kontekstual}

Pembelajaran kontextual (Contextual Teaching and Learning (CTL)) adalah konsep belajar yang membantu guru mengaitkan antara materi yang diajarkannya dengan situasi dunia nyata siswa dan mendorong siswa membuat hubungan antara pengetahuan yang dimilikinya dengan penerapannya dalam kehidupan mereka sehari-hari, dengan melibatkan 7 (tujuh) komponen utama pembelajaran efektif yakni: konstruktivisme (Construktivism), bertanya (Questioning) menemukan (Inquiry) masyarakat belajar (Learning Community), refleksi (reflection )pemodelan 
(Modeling) dan penilaian sebenarnya (Authentic Assessment) (Nurhadi, 2002; Murtalib dkk, 2021; Wahyuningsih, 2021).

Secara sederhana perbedaannya dengan pengajaran konvensional, yang biasa kita kerjakan adalah pengajaran yang berjalan selama ini terlalu teoritis relatif jauh dari realita kehidupan siswa, siswa banyak dijejali dan mengingat fakta, sementara untuk apa fakta tersebut dipakai dalam pemecahan masalah sehari-hari, siswa tidak banyak tahu. Nah, KBK dengan CTL-nya berupaya mendekatkan antara pengetahuan dengan keterampilan penerapannya dalam memecahkan masalah kehidupan nyata.

CTL barangkali dari segi istilah relatif baru, tetapi sesungguhnya sebagian guru telah menerapkannya dalam proses pembelajaran di kelas. Seorang guru telah menerapkan CTL dalam proses pembelajaran apabila 7 (tujuh) komponen utama CTL diatas muncul dalam Proses Pembelajaran. Penerapan Tujuh Komponen CTL dalam Proses Belajar Mengajar: 1) Konstruktivisme (Construktivism); 2) Menemukan (Inquiry); 3) Langkah kegiatan Inquiry; 4) Bertanya (Questioning); 5) Masyarakat Belajar (Learning Community); 6) Pemodelan (Modeling); 7) Refleksi (reflection ); dan 8) Penilaian Sebenarnya (Authentic Assessment).

\section{Hasil Belajar}

Berikut ini pengertian hasil belajar menurut pendapat para ahli, diantaranya: Menurut Nana Syaodih Sukmadinata hasil belajar merupakan realisasi potensial atau kapasitas yang dimiliki seseorang. Penguasaan hasil belajar seseorang dapat dilihat dari perilakunya, baik perilaku dalam bentuk penguasaan pengetahuan, keterampilan berfikir maupun keterampilan motorik. Menurut Asep Jihad hasil belajar adalah perubahan tingkah laku siswa secara nyata setelah dilakukan proses pembelajaran yang sesuai tujuan pembelajaran. Menurut Winkel hasil belajar adalah perubahan yang mengakibatkan manusia berubah dalam sikap dan tingkah lakunya. Menurut Gagne dan Briggs hasil belajar adalah sebagai kemampuan yang diperoleh seseorang sesudah mengikuti proses belajar. Ruang lingkup hasil belajar adalah perilakuperilaku kejiwaan yang akan diubah dalam proses pendidikan. Perilaku kejiwaan itu diklasifikasi dalam tiga domain yaitu Ranah Kognitif, Ranah afektif, dan Ranah Psikomotor.

\section{Mulok sebagai mata pelajaran dalam Kurikulum 2013 SMA}

Keadaan daerah adalah segala sesuatu yang terdapat di daerah tertentu yang pada dasarnya berkaitan dengan lingkungan alam, lingkungan sosial ekonomi, dan lingkungan sosial budaya. Kebutuhan daerah adalah segala sesuatu yang diperlukan oleh masyarakat di suatu daerah, khususnya untuk kelangsungan hidup dan peningkatan taraf kehidupan masyarakat tersebut, yang disesuaikan dengan arah perkembangan daerah serta potensi daerah yang bersangkutan.

Muatan lokal, sebagaimana dimaksud dalam Penjelasan Atas Undang-undang Nomor 20 Tahun 2003 tentang Sistem Pendidikan Nasional, merupakan bahan kajian yang dimaksudkan untuk membentuk pemahaman peserta didik terhadap potensi di daerah tempat tinggalnya. Dalam Pasal 77 N Peraturan Pemerintah Nomor 32 Tahun 2013 tentang Perubahan Atas Peraturan Pemerintah Nomor 19 Tahun 2005 tentang Standar Nasional dinyatakan bahwa : (1) Muatan lokal untuk setiap satuan pendidikan berisi muatan dan proses pembelajaran tentang potensi dan keunikan lokal; (2) Muatan lokal dikembangkan dan dilaksanakan pada setiap satuan pendidikan. 
Selanjutnya, dalam Pasal 77P antara lain dinyatakan bahwa : (1) Pemerintah daerah provinsi melakukan koordinasi dan supervisi pengelolaan muatan lokal pada pendidikan menengah; (2) Pemerintah daerah kabupaten/kota melakukan koordinasi dan supervisi pengelolaan muatan lokal pada pendidikan dasar; (3) Pengelolaan muatan lokal meliputi penyiapan, penyusunan, dan evaluasi terhadap dokumen muatan lokal, buku teks pelajaran, dan buku panduan guru; dan (4) Dalam hal seluruh kabupaten/kota pada 1 (satu) provinsi sepakat menetapkan 1 (satu) muatan lokal yang sama, koordinasi dan supervisi pengelolaan kurikulum pada pendidikan dasar dilakukan oleh pemerintah daerah provinsi.

\section{METODE PENELITIAN}

\section{Lokasi Waktu dan Subyek Perbaikan}

a. Lokasi Perbaikan

Perbaikan ini dilakukan di SMAN 4 Kota Bima.

b. Waktu Perbaikan

Perbaikan dilaksanakan dalam 2 (dua) siklus. Siklus I dari tanggal 13 Juli 2019 sampai dengan 24 Juli 2019 dan siklus II dilaksanakan tanggal 16 Agustus 2019 sampai dengan 27 Agustus 2019.

c. Pembelajaran

Pembelajaran yang dilakukan perbaikan merupakan Mulok kelas X MIPA-2 semester I.

\section{Subyek Perbaikan}

Subyek perbaikan adalah siswa kelas X MIPA-2 SMAN 4 Kota Bima dengan jumlah siswa 31, terdiri dari 13 orang laki-laki dan 18 orang perempuan. Adapun karakteristik siswa rata-rata memiliki intake, kemampuan akademik yang sedang. Kreativitas dan motivasi belajar siswa rata-rata rendah.

Adapun faktor-faktor yang akan diteliti adalah:

a. Hasil belajar siswa, sejauh hasil belajar siswa pada pembelajaran Mulok materi ragam patu mbojo.

b. Kinerja guru, diteliti sejauh mana ketuntasan guru dalam perencanaan dan pelaksanaan pembelajaran sesuai dengan instrument yang telah ditetapkan yakni menggunakan APKG I dan APKG II.

\section{Pihak yang Membantu}

Adapun pihak-pihak yang membantu dalam penelitian ini adalah:

a) Kepala SMAN 4 Kota Bima

b) Supervisor 2, guru senior di SMAN 4 Kota Bima

c) Guru teman sejawat, sebagai observer dalam pelaksanaan penelitian

d) Siswa-siswi SMAN 4 Kota Bima

\section{Desain Prosedur Perbaikan Pembelajaran}

a. Data dan Cara Pengambilannya

1) Sumber data: sumber data perbaikan ini adalah seluruh siswa-siswi kelas $X$ MIPA-2 SMAN 4 Kota Bima.

2) Jenis data :

a) Data kualitatif terdiri dari:

(1) Teacher's note RPP (Rencana Pelaksanaan Pembelajaran)

(2) Data hasil observasi pelaksanaan pembelajaran dan activitas siswa.

(3) Jurnal tim peneliti 
b) Data Kuantitatif

(1) Nilai pos tes

(2) Nilai Kinerja guru

3) Teknik Pengambilan data

(a) Data kualitatif diambil dari teacher's note RPP (Rencana Pelaksanaan Pembelajaran) yang dibuat peneliti.

(b) Data tentang refleksi diri diambil dari jurnal yang dibuat oleh peneliti.

(c) Data kuantitatif diambil dari skor nilai tes siswa.

b. Indikator Kinerja

1. Hasil belajar siswa: ketuntasan individual 75 , ketuntasan klasikal $85 \%$ dengan rata-rata minimal 75 .

2. Kinerja Guru, ketuntasan guru dalam menyelesaikan Rencana Pelaksanaan Pembelajaran dalam APKG I $\geq 92.00$.

3. Kinerja Guru, ketuntasan guru dalam Pelaksanaan Pembelajaran dalam APKG II $\geq 92.00$.

4. Intrumen Perbaikan

a) Instrumen perbaikan berupa performance test.

b) Lembar observasi kinerja guru.

\section{Deskripsi Per-siklus/Desain Perbaikan}

\section{Siklus Perbaikan}

Siklus perbaikan dilaksanakan dalam dua siklus. Tiap siklus terdiri dari 4 (empat) tahapan utama yakni: perencanaan; penggunaan tindakan; observasi dan refleksi. Hasil refleksi akan menentukan apakah perbaikan dengan langkah-langkah PTK dalam siklus tersebut berhasil atau belum berhasil. Jika belum berhasil maka akan dilanjutkan pada siklus berikutnya.

\section{Siklus Pertama}

Tahap-tahap perbaikan tindakan siklus pertama

(1) Perencanaan

Dalam tahap perencanaan ini kegiatan pokok yang dilakukan adalah Menyusun jadwal perbaikan; menyiapkan instrument pengamatan perbaikan; menyusun Rencana Pembelajaran (RPP); dan Mempersiapkan materi pembelajaran.

(2) Pelaksanaan Tindakan

Melaksanakan pembelajaran dengan mengacu pada penataan skenario pembelajaran yang termuat dalam rencana pelaksanaan perbaikan pembelajaran.

(3) Observasi

Dalam observasi ini peneliti mengobservasi seluruh rangkaian kegiatan proses pembelajaran apakah dapat berjalan seperti yang direncanakan atau tidak. Di sini peneliti dan observer melakukan pencatatan item-item kegiatan yang secara signifikan mempengaruhi proses pembelajaran, baik yang berpengaruh positif maupun negative. Obyek observasi meliputi aktivitas guru, siswa, serta efektivitas media yang digunakan. Observer juga menggunakan lembar observasi dengan mengisi item-item butir observasi yang telah dipersiapkan.

Dalam observasi ini akan menentukan ketercapaian indikator-indikator utama yang menjadi tolok ukur keberhasilan perbaikan ini, termasuk kemampuan guru dalam melaksanakan dan menyelesaikan Rencana 
Pembelajaran (RPP) dengan langkah pembelajaran Mulok mengacu pada sumber belajar dengan internet.

(4) Refleksi

Dengan menganalisa hasil observasi maka dilakukan refleksi, merenungkan kembali apa yang telah peneliti lakukan. Kegiatan refleksi ini bertujuan untuk:

\section{Siklus Kedua}

Kegiatan pada siklus kedua merupakan rangkaian kegiatan yang tidak teroisahkan dengan kegiatan siklus pertama. Langkah-langkah kegiatan siklus kedua tidak jauh berbeda dengan siklus pertama. Disini langkah-langkah direncanakan dan dilaksanakan berdasarkan hsil refleksi Penggunaan tindakan siklus pertama. Langkah-langkah utama tersebut adalah Perencanaan, Penggunaan tindakan, Observasi, dan Refleksi.

\section{Teknik Pengumpulan Data}

Teknik pengumpulan data yang digunakan dalam penelitian ini terdiri dari 2 teknik, yaitu teknik observasi dan teknik tes.

1) Teknik Observasi

Observasi dilakukan selama kegiatan pembelajaran berlangsung dengan menggunakan lembar observasi yang dibuat untuk digunakan sebagai perangkat pengumpul data. Adapun hal-hal yang diobservasi antara lain:

a) Observasi terhadap rencana pembelajaran.

b) Observasi terhadap proses pelaksanaan pembelajaran.

c) Observasi terhadap hasil yang diperoleh siswa setelah dilakukan tindakan.

2) Teknik Tes

Teknik tes dilakukan pada akhir kegiatan pembelajaran dengan menggunakan lembar soal untuk mengetahui hasil belajar siswa.

3) Alat Pengumpulan Data

Alat pengumpulan data yang digunakan dalam penelitian ini adalah (1) Butir Soal, (2) Lembar Observasi, (3) Observasi terhadap rencana pembelajaran, (4) Observasi terhadap proses pembelajaran, (5) Observasi terhadap hasil yang diperoleh siswa setelah dilakukan tindakan.

\section{Teknik Analisis Data}

Teknik analisis data yang digunakan ada yang bersifat kuantitatif dan kualitatif. Data yang diperoleh dikatagorikan dan diklasifikasikan berdasarkan analisis kaitan logisnya, kemudian disajikan secara aktual dan sistematis dalam keseluruhan permasalahan dan kegiatan penelitian.

\section{HASIL DAN PEMBAHASAN}

\section{Deskripsi Hasil Penelitian Perbaikan Pembelajaran \\ Hasil Perbaikan}

\section{a. Perencanaan}

Pendekatan kontekstual adalah metode yang spesifik yang memiliki 7 fase pembelajaran: konstruktivisme (Construktivism), bertanya (Questioning) menemukan (Inquiry) masyarakat belajar (Learning Community), refleksi (reflection )pemodelan (Modeling) dan penilaian sebenarnya (Authentic Assessment) yang perlu diikuti 
dalam penerapannya. Agar pembelajaran dapat optimal diterapkan pada pembelajara Mulok materi ragam patu mbojo peneliti mempersiapkan siswa untuk belajar aktif, baik dalam kelompok maupun secara individual.

Selain itu penguasaan teknologi informasi berkaitan dengan pemanfaatan informasi internet khususnya searching untuk mendapatkan informasi beerkaitan materi pembelajaran peneliti asumsiikan tidak ada hambatan, karena siswa sudah terbiasa menggunakan internet.

Sehingga dalam Rencana Pelaksanaan Pembelajaran (RPP) pada kegiatan inti, substansi pembelajaran didesain dalam kegiatan pembelajaran dengan memperhatiikan 7 fase pembelajaran dengan menggunakan pendekatan kontekstual pada kegiatan inti.

Dengan perencanaan yang matang mengacu pada rambu-rambu pembelajaran yang ada maupun rujukan pendapat para pakar pembelajaran akhirnya RPP dapat disusun dengan baik dengan menggunakan langkah-langkah 7 fase pembelajaran Pendekatan kontekstual ditunjang sumber belajar dengan mnggunakan internet.

\section{b. Pelaksanaan}

Secara keseluruhan pelaksanaan pembelajaran dengan pembelajaran 7 fase pembelajaran Pendekatan kontekstual menggunakan internet sebagai sumber belajar mata pelajaran Mulok materi ragam patu mbojo telah berjalan dengan baik akan tetapi belum optimal. Adapun prestasi belajar (pos tes) dan kinerja guru Siklus I dilanjutkan data prestasi belajar (pos tes) dan kinerja guru Siklus II sebagai berikut:

Penerapan tindakan belum sesuai dengan rencana, dan peneliti belum merasa puas baik dari sisi proses mapun hasilnya. Adapun hasil post test dan kinerja guru siklus I yang dilanjutkan Siklus II sebagai berikut:

Tabel 1. Prestasi belajar siswa

\begin{tabular}{|c|r|r|r|r|r|}
\hline \multicolumn{2}{|c|}{ Prasiklus } & \multicolumn{2}{c|}{ Siklus I } & \multicolumn{2}{c|}{ Siklus II } \\
\hline $\begin{array}{c}\text { Rata- } \\
\text { rata }\end{array}$ & $\begin{array}{c}\% \\
\text { ketercapaian }\end{array}$ & $\begin{array}{c}\text { Rata- } \\
\text { rata }\end{array}$ & $\begin{array}{c}\% \\
\text { ketercapaian }\end{array}$ & $\begin{array}{c}\text { Rata- } \\
\text { rata }\end{array}$ & $\begin{array}{c}\% \\
\text { ketercapaian }\end{array}$ \\
\hline 65.00 & $68.00 \%$ & 68.44 & $71.00 \%$ & 80.00 & $85.00 \%$ \\
\hline
\end{tabular}

Tabel 2. Kinerja guru

\begin{tabular}{|r|c|c|c|c|c|}
\hline \multicolumn{2}{|c|}{ Prasiklus } & \multicolumn{2}{c|}{ Siklus I } & \multicolumn{2}{c|}{ Siklus II } \\
\hline APKG I & $\begin{array}{c}\text { APKG } \\
\text { II }\end{array}$ & $\begin{array}{c}\text { APKG } \\
\text { I }\end{array}$ & $\begin{array}{c}\text { APKG } \\
\text { II }\end{array}$ & $\begin{array}{c}\text { APKG } \\
\text { I }\end{array}$ & $\begin{array}{c}\text { APKG } \\
\text { II }\end{array}$ \\
\hline 88.00 & 85.00 & 90.5 & 89.00 & 92.20 & 92.30 \\
\hline
\end{tabular}

\section{c. Observasi}

Kegiatan observasi dilakukan oleh observer mengamati jalannya proses pembelajaran melalui penerapan pendekatan kontekstual dengan memanfaatkan media internet sebagai sumber belajar dengan pemanfaatan internet sebagai sumber belajar siswa kelas X MIPA-2 SMAN 4 Kota Bima pada pembelajaran Mulok ragam patu mbojo. Dalam observasi ini observer menggunakan lembar observasi dimana dalam format lembar observasi mengacu pada instrumen penilaian kinerja guru yang didalamnya memeuat RPP 7 fase pembelajaran pendekatan kontekstual dengan memanfaatkan media internet sebagai sumber belajar dengan langkah-langkah pembelajaran yang telah disusun. Kompetensi guru diukur dalam merencanakan dan melaksanakan kegiatan pembelajaran. 
Ketuntasan guru dalam melaksanakan kinerja guru kompetensi guru dalam melaksanakan kegiatan pembelajaran yang mendidik disajikan dalam prosen (\%).

\section{Pembahasan Per Siklus}

\section{Pembahasan Siklus I}

a. Hasil Belajar

Pembelajaran Mulok materi ragam patu mbojo, dari tabel 1 hasil pos tes siklus I diatas menunjukkan bahwa prestasi belajar siswa rata-rata 68.44. Meskipun nilai rata-rata ini telah mengalami peningkatan dibanding sebelum diadakan perbaikan (+3.44), tetapi nilai ini belum memenuhi indikator kinerja yang ditetapkan yakni rata-rata $\geq 75.00$. Persentase ketuntasan $71.00 \%$ nilai rata-rata ini telah mengalami peningkatan dibanding sebelum diadakan perbaikan (+3.00), Persentase ini masih dibawah indikator kinerja yakni $\geq 85.00 \%$. Dari sisi prestasi belajar siklus I (pertama) belum berhasil.

b. Kinerja Guru

Pembelajaran Mulok materi ragam patu mbojo. Skor kinerja guru kompetensi guru APKG I, untuk perencanaan pembelajaran yang mendidik $\geq 90.50$ nilai ini mengalami penngkatan dibanding sebelum diadakan perbaikan $(+2.00)$ APKG II, untuk pelaksanaan pembelajaran yang mendidik $\geq 89.00$ meskipun nilai ini mengalami penngkatan dibanding sebelum diadakan perbaikan $(+4.00)$ tetapi masih terdapat 7 deskriptor yang sebagian dilaksanakan (sebagain terpenuhi) dan 4 deskriptor seluruhnya dilaksanakan (seluruhnya terpenuhi). Dengan demikian dari sisi kinerja guru siklus I belum mencapai indikator kinerja yang ditetapkan yakni APKG I dan APKG II $\geq 92.00$.

c. Refleksi

Data dan pembahasan diatas menunjukkan bahwa dari komponen Rencana Pembelajaran (RPP) sudah cukup bagus. Belum tercapainya indikator prestasai belajar siswa disebabkan guru belum mampu melaksanakan secaara optimal 11 langkah yang ditetapkan dalam RPP. Dengan demikian dari aspek Rencana Pembelajaran tidak perlu diganti atau direvisi. Yang perlu diperbaiki adalah pelaksanaan pembelajaran di kelas khususnya pada hal-hal sebagai berikut:

\section{Pendahuluan}

1) Konstruktivisme (Construktivism)

Dalam guru perlu memotivasi siswa secara intensif sehingga seluruh siswa dapat melantunkan Patu Mbojo.

\section{Inti}

2) Menemukan (Inquiry)

Guru perlu memberikan petunjuk yang jelas sehingga siswa dalam mencari sumber belajar dari internet dan mengamati video Patu Mbojo yang dilantunkan dengan biola dan disuruh memberikan komentar dapat melaksanakan dengan tepat.

3) Bertanya (Questioning)

Bertanya merupakan strategi utama pembelajaran berbasis CTL. Manfaat bertanya: Dalam menanyakan respons siswa terhadap Patu Mbojo, guru perlu memberikan rambu-rambu cara memberikan respons yang tepat, sehingga seluruh siswa dapat memberikan respons dengan tepat pula.

4) Masyarakat Belajar (Learning Community) 
Dalam pembentukan kelompok guru perlu memperhatikan homoginitas anggota kelompok sehingga tidak disominasi kelompook yang anggotanya pintar-pintar.

5) Pemodelan (Modeling)

Dalam memberikan contoh, guru perlu memberikan contoh yang tepat, banyak dan jelas sehingga dapat memperluas wawasan dan pilihan bagi siswa.

6) Penilaian Sebenarnya (Authentic Assessment).

Siswa ditugaksan untuk menyusun Patu Mbojo secara individual dengan memilih tema sesuai dengan contoh yang diberikan guru. Guru perlu memastikan seluruh siswa dapat mengerjakan tugasnya.

\section{Pembahasan Siklus Kedua (II)}

a. Perencanaan

Perencanaan siklus II dilakukan dengan mempertimbangkan hasil refleksi siklus I. Fokus perencanaan pada rencana perbaikan pelaksanaan proses pembelajaran.

b. Penerapan Tindakan

Rencana Pembelajaran tidak mengalami perubahan Pelaksanaan pembelajaran dilakukan perubahan pada langkah-langkah:

\section{Pendahuluan}

1) Konstruktivisme (Construktivism)

Dalam guru dapat memotivasi siswa secara intensif sehingga seluruh siswa dapat melantunkan Patu Mbojo.

\section{Inti}

2) Menemukan (Inquiry)

Guru mampu memberikan petunjuk yang jelas sehingga siswa dalam mencari sumber belajar dari internet dan mengamati video Patu Mbojo yang dilantunkan dengan biola dan disuruh memberikan komentar dapat melaksanakan dengan tepat.

3) Bertanya (Questioning)

Bertanya merupakan strategi utama pembelajaran berbasis CTL. Manfaat bertanya: Dalam menanyakan respons siswa terhadap Patu Mbojo, guru telah memberikan rambu-rambu cara memberikan respons yang tepat, sehingga seluruh siswa dapat memberikan respons dengan tepat pula.

4) Masyarakat Belajar (Learning Community)

Dalam pembentukan kelompok guru melakukan memperhatikan homoginitas anggota kelompok sehingga tidak disominasi kelompok yang anggotanya pintar-pintar.

5) Pemodelan (Modeling)

Dalam memberikan contoh, guru telah memberikan contoh yang tepat, banyak dan jelas sehingga dapat memperluas wawasan dan pilihan bagi siswa.

6) Penilaian Sebenarnya (Authentic Assessment).

Siswa ditugaksan untuk menyusun Patu Mbojo secara individual dengan memilih tema sesuai dengan contoh yang diberikan guru. Guru berhasil memastikan seluruh siswa dapat mengerjakan tugasnya. 


\section{a. Observasi}

Dalam kegiatan ini langkah-langkah observasi siklus II ini tidah jauh berbeda dengan yang dilaksanakan pada siklus I. Observer menggunakan lembar observasi kinerja guru untuk mengamati seluruh pelaksanaan proses pembelajaran. Hasilnya dideskrisikan sebagai berikut:

\section{Hasil Belajar}

Pembelajaran Mulok materi ragam patu mbojo. Dari tabel 2 hasil pos tes siklus II diatas menunjukkan bahwa prestasi belajar siswa rata-rata 80.00. Nilai rata-rata ini telah mengalami peningkatan dibanding sebelum diadakan perbaikan $(+11.56)$. Persentase ketuntasan $85.00 \%$, mengalami peningkatan dibanding sebelum diadakan perbaikan (+14.00). Persentase ini telah memenuhi indikator kinerja yakni $\geq 85.00 \%$. Dengan demikian pada siklus II ini telah berhasil mencapai indikator yang ditetapkan yakni rata-rata $\geq 75.00$ dan persentase ketuntasan $\geq 85.00 \%$. Dari sisi prestasi belajar siklus II (kedua) telah berhasil.

\section{Kinerja Guru}

Pembelajaran Mulok materi ragam patu mbojo. Skor kinerja guru menunjukkan bahwa skor ketuntasan guru APKG I, untuk perencanaan pembelajaran yang mendidik $\geq 92.20$ nilai ini mengalami peningkatan dibanding siklus I $(+1.70)$ APKG, II untuk pelaksanaan pembelajaran yang mendidik $\geq 92.30$ nilai ini mengalami peningkatan dibanding siklus I (+3.30). Dengan perbaikan proses pembelajaran berhasil memenuhi indikator kinerja yang ditetapkan yakni APKG I, untuk perencanaan $\geq 92.00$ APKG II, untuk pelaksanaan $\geq 92.00$.

b. Refleksi

Penerapan pendekatan kontekstual dengan memanfaatkan media internet sebagai sumber belajar dengan pemanfaatan internet sebagai sumber belajar membuthkan kesiapan guru dan siswa. Hal ini berbeda dengan penerapan metode ceramah ataupun metode tanya jawab. Kesiapan guru jelas karena guru sebagai desainer pembelajaran. Kesiapan siswa diperlukan untuk mengetahui tugas masingmasing siswa karena dalam proses pembelajaran.

Memahami kunci 7 fase pembelajaran pendekatan kontekstual dengan memanfaatkan media internet sebagai sumber belajar dengan pemanfaatan internet sebagai sumber belajar menjadi kunci keberhasilan penerapan metode pembelajaran tersebut. Peneliti pada siklus II telah berhasil mengatasi kendala utama tersebut, sehingga pembelajaran dapat berjalan sesuai dengan RPP, dan sesuai dengan harapan peneliti. Pada siklus II ini peneliti telah merasa puas dengan proses pembelajaran dan prestasi belajar yang dicapai, sehingga tidak perlu lagi dilanjutkan ke siklus berikutnya.

c. Observasi

Kegiatan observasi dilakukan oleh observer mengamati jalannya proses pembelajaran. Dalam observasi ini observer menggunakan lembar observasi dimana dalam format lembar observasi mengacu pada instrumen penilaian kinerja guru APKG I untuk perencanaan pembelajaran dan APKG II untuk pelaksanaan pembelajaran. Kompetensi guru dalam perencanaan dan melaksanakan perencanaan dan pelaksanaan pembelajaran.

\section{Pembahasan Hasil Penelitian Perbaikan Pembelajaran}


Setelah melewati 2 (dua) siiklus dimana peneliti telah berupaya medesain Rencana Pelaksanaan Pembelajaran (RPP) dan melaksanakan pembelajaran sesuai dengan Permendikbud Nomor 22 Tahun 2016 tentang Standar Proses. Demikian pula RPP telah dirancang dengan mengacu pada Pengembangan pembelajaran dan mengacu pada karakteristik pendekatan kontekstual dengan memanfaatkan media internet sebagai sumber belajar dengan pemanfaatan internet sebagai sumber belajar, maka sampai akhir siklus II seluruh indikator knerja dapat dicapai.

Dari keseluruhan analisis data dan pembahasan diatas secara umum pelaksanaan PTK baik dari aspek hasil belajar siswa maupun kinerja guru telah berhasil mencapai indikator kinerja yang diharapkan. Dengan hasil tersebut siklus II dinyatakan berhasil mencapai indikator kinerja yang ditetapkan dan tidak perlu lagi dilanjutkan pada siklus berikutnya.

\section{KESIMPULAN}

Adapun kesimpulan dari hasil penelitian ini sebagai adalah 1) Penerapan Pendekatan Kontekstual dengan Memanfaatkan Internet Sebagai Sumber Belajar untuk Meningkatkan Hasil Belajar Siswa pada Mata Pelajaran Mulok Materi Ragam Patu Mbojo di SMAN 4 Kota Bima Kelas X MIPA-2 Semester Ganjil Tahun Pelajaran 2020/2021; 2) Penerapan penerapan pendekatan kontekstual dengan memanfaatkan media internet sebagai sumber belajar dapat meningkatkan kinerja guru kelas X MIPA-2 SMAN 4 Kota Bima pada pembelajaran Mulok materi ragam patu mbojo semester I tahun pelajaran 2020/2021.

Saran dan Tindak Lanjut dari hasil penelitian ini: 1) Kepada guru yang melaksanakan pembelajaran disarankan menerapkan pendekatan kontekstual dengan memanfaatkan media internet sebagai sumber belajar dalam meningkatkan hasil belajar Mulok; 2) Kepada guru, disarankan untuk memperhatikan rambu-rambu yang dimuat dalam Permendikbud Nomor 22 Tahun 2016 tentang standar proses dalam perencanaan dan pelaksanaan pembelajaran; 3) Kepada Kepala Sekolah disarankan untuk proaktif memotivasi guru agar secara kontinyu memperbaiki pembelajaran, memanfaatkan hasil peneltian guru guna peningkatan kualitas pembelajaran di sekolah; dan 4) Kepada instansi terkait, disarankan untuk mendorong guru-guru yang untuk melakukan inovasi pembelajaran dalam rangka meningkatkan kualitas pembelajarannya.

\section{DAFTAR PUSTAKA}

Arikunto, Suharsimi. (2003). Prosedur Penelitian, Suatu Praktek. Jakarta: Bina Aksara.

Arif S. Sadiman Dkk. (1984). Media Pendidian Pengertian Pengembangan danManfaatya: Jakarta : pustekom Dikbud An PT. Raja GrafindoPersada.

Amri. Sofan (2013). Pengembangan \& Model Pembelajaran Dalam Kurikulum 2013. Jakarta: PT. Prestasi Pustakakarya. 
Busono, G. A. (2016). Pengaruh Sistem Pelatihan Dan Pengembangan Karyawan Terhadap Kinerja Karyawan Pt. Persada Sawit Mas (PSM) Kecamatan Pampangan Kabupaten Ogan Komering Ilir.Muqtashid, 1(1), 81-114.

Budiyanto, Agus Krisno. (2016). Sintaks 45 Model Pembelajaran dalam Student Centered Learning (SCL). Malang : Universitas Muhammadiyah Malang Press.

Depdiknas. (2003). Undang-undang RI No.20 tahun 2003.tentang sistem pendidikan nasional.

Elizabeth B. Hurlock. (1978). Perkembangan Anak: Jakarta: Penerbit Erlangga.

Hamalik, Oemar. (2010). Proses Belajar Mengajar. Jakarta: PT Bumi Aksara.

Hadi, S., Tukiran, T., \& Yuwono, B. 2009. Pengaruh Supervisi Akademik, Kompetensi Guru dan Kedisiplinan Terhadap Kinerja Guru SMA Negeri 3 Slawi Kabupaten Tegal.Khazanah Pendidikan, 2(1).

Wardani, I.G.A.K. (2019). Pemantapan Kemampuan Profesional. Jakarta: Universitas Terbuka KTSP SD/MI 2019.

Kemendikbud. (2016). Permendikbud Nomor 22 Tahun 2016 Tentang Standar Proses Pendidikan Dan Menengah. Jakarta: Kemendikbud.

Kementerian Pendidikan Nasional. Direktorat Jenderal Peningkatan Mutu Pendidik dan Tenaga Kependidikan. (2010). Pedoman Pelaksanaan Penilaian Kinerja Guru(PK Guru). Jakarta. www.bermutuprofesi.org.

Kartowagiran, B. (2011). Kinerja Guru Profesional (Guru Pasca Sertifikasi).Jurnal Cakrawala Pendidikan, 3(3).

Mulyatiningsih, E. (2011). Metode Penelitian Terapan Bidang Pendidikan. Yogyakarta: Alfabeta.

Minarsih, M. M. (2015). Analisis Pengaruh Kepemimpinan Transformasional, Moral Dan Komitmen Organisasi Terhadap Organizational Citizenship Behavior Dalam Meningkatkan Kinerja Guru Sekolah Dasar Swasta di Kecamatan Pedurungan Kota Semarang.Jurnal Mulok dan Bisnis Kontemporer, 1(01).

Murtalib, M., Dusalan, D., Marweli, M., \& Rohana, R. (2021). Penerapan Pendekatan Kontekstual pada Materi Pokok Trigonometri untuk Meningkatkan Prestasi Belajar Siswa. Jurnal Pendidikan dan Pembelajaran Indonesia (JPPI), 1(1), 22-29.

Nana Sudjan. (2010). Dasar-dasar Proses Belajar, Sinar Baru Bandung.

Nuchiyah, Nunu. (2007). Pengaruh Kepemimpinan Kepala Sekolah dan Kinerja Mengajar Guru Terhadap Prestasi Belajar Siswa. Jurnal Pendidikan Dasar. Vol.5 no.7: $1-4$

PermendikbudRepublik Indonesia Nomor 69 (2013). Tentang Kerangka Dasar dan Struktur Kurikulum Sekolah Menengah Atas/Madrasah Aliyah.

Sukmadinata, Nana Syaodih. (2009). Metode Penelitian Pendidikan. Bandung: Remaja Rosdakarya. 
Wahyuningsih, S. (2021). Pembelajaran Berbasis Konstruktivisme untuk Meningkatkan Aktivitas dan Prestasi Belajar Siswa pada Materi Pokok Himpunan. Jurnal Pendidikan dan Pembelajaran Indonesia (JPPI), 1(1), 10-21.

Wayan Sukaryana (1999). PTK (Classroom action resersh). Jakarta: Depdikbud.

Winkel, W. S. (2004). Psikologi Pendidikan dan Evaluasi Belajar. Jakarta: PT. Gramedia Pustaka Utama.

Warsita, Bambang. (2008). Teknologi Pembelajaran: Landasan \&Aplikasinya, Jakarta: Rineka. 